\title{
Content Adequacy of Oral Literature in Selected English Studies Textbooks: Implications for Inculcating Moral Values into In-School Adolescents
}

\author{
Ifeoluwa Theophilus Akinsola $^{1 *}$ and Bolape Olufunto Olaosebikan ${ }^{2}$ \\ ${ }^{1,2}$ University of Ibadan, Nigeria \\ Email: ifeoluwa.akinsola@gmail.com
}

\begin{abstract}
Textbooks are essential resources in the teaching-learning process. The integration of English language and literature called English Studies at the junior secondary schools in Nigeria has brought about textbooks incorporating both language and literature (oral and written) components. This study was carried out to analyze the content adequacy of oral literature incorporated in New Oxford Secondary English Course for Junior Secondary Schools and New Concepts English Textbooks and investigate teachers' perceptions. Book one to three of the two textbooks was purposively selected because they were used in the selected junior secondary schools for this study. The study, hence, adopted a mixedmethods of data collection and analysis. The textbooks selected were content analyzed by drawing out their oral literature components. Quantitative data were collected using a self-constructed questionnaire from 50 teachers of English studies randomly selected across 25 junior secondary schools in the Ibadan metropolis. The content analysis done of the selected textbooks was compared with the teachers' perception of the adequacy of the textbooks in inculcating moral values into students. The study recommended, among others, that English teachers at the junior secondary school level should actively implement the oral literature content of the English studies textbook with the use of appropriate teaching methods, strategies, and instructional materials.
\end{abstract}

Keywords:

Oral Literature; Textbooks; Language; English Studies; Moral Values.

\begin{abstract}
ABSTRAK
Buku teks merupakan sumber penting dalam proses belajar-mengajar. Integrasi bahasa dan sastra Inggris yang disebut Studi Bahasa Inggris di sekolah menengah pertama di Nigeria telah menghasilkan produksi buku
\end{abstract}


teks yang menggabungkan komponen bahasa dan sastra (lisan dan tulisan). Penelitian ini dilakukan untuk menganalisis kecukupan konten sastra lisan yang tergabung dalam Kursus Bahasa Inggris Menengah Baru Oxford untuk Sekolah Menengah Pertama dan Buku Teks Bahasa Inggris Konsep Baru dan untuk menyelidiki persepsi guru tentang hal yang sama. Buku satu sampai tiga dari dua buku teks dipilih secara purposive karena merupakan buku teks yang digunakan di sekolah menengah pertama yang dipilih untuk penelitian ini. Oleh karena itu, penelitian ini mengadopsi metode pengumpulan dan analisis data campuran. Buku teks yang dipilih dianalisis isinya dengan menggambar komponen sastra lisannya. Data kuantitatif dikumpulkan dengan menggunakan kuesioner yang dibuat sendiri dari 50 guru studi bahasa Inggris yang dipilih secara acak di 25 sekolah menengah pertama di metropolis Ibadan. Analisis isi yang dilakukan terhadap buku teks terpilih dibandingkan dengan persepsi guru tentang kecukupan buku teks dalam menanamkan nilai-nilai moral kepada siswa. Studi ini merekomendasikan antara lain, bahwa guru bahasa Inggris di tingkat sekolah menengah pertama harus secara aktif menerapkan isi literatur lisan dari buku pelajaran bahasa Inggris dengan menggunakan metode pengajaran, strategi dan bahan ajar yang tepat.

\section{Kata Kunci:}

Sastra Lisan; Buku Teks; Bahasa; Studi Bahasa Inggris; Nilai Moral.

\section{Introduction}

Oral literature is that literary form that has its basis in culture. It is the verbal or oral form of literature that incorporates the rich, diverse oral traditions-folklore, myths, proverbs, and folksong of a society. Nnyagu (2017) views the term 'Oral Literature' as oxymoronic since oral means that which is not written but spoken to be listened to and literature written down to be read. This then posits that literature is not just what is written down but also what is spoken. Before the African colonization, Africans were only part-literate in their various indigenous languages because they could only speak it but not write it down. They had their history, stories, and social realities, which they record in their proverbs, idioms, folklore, praise poetry, and songs and passed through generations. The communal way of passing this information ensured its sustainability through many years. However, colonization with its modern education brought about the documentation of the African oral literature, and eventually, oral literature in Nigeria and other African communities began to be written down and translated into multiple languages.

Before the advent of modern education, parents and elders usually express their values, norms, culture, and ideas orally in their indigenous languages. Through this medium, they subconsciously and consciously transmit those sacrosanct ideas to their children through traditional and formal politics, religion, culture, family, etc. (Amin Mt \& Ahmed, 2021; Fafunwa, 1991). During this period, society is mainly communal, so everyone, the parents, family members, and even neighbors, is expected to train up children. Nwakaego (2016) reveals that society usually uses folktales, 
folksongs, riddles, and proverbs as pedagogic tools for supplementing any deficiency they note in children's values and behaviors.

Mothers start training children even right from home through proverbs, lullabies, and folktales. Moreover, as children grow up, they can imbibe those values that are core to society. Those days, children would be gathered under the moonlight at the market square or in front of their homes while the older women in the family narrate proverbs, folktales, and riddles about some legendary animals like the grasshoppers, tortoise, dog, ants, elephant, lion and hare. After recounting their stories via artistic and emotive language, folksongs, gesticulations, and tonal fluctuations to draw children's attention and make their stories real, the narrators would then interpret them according to the way the society construes the world centering on projecting and propagating the values, virtues, and morals that are sacrosanct to them. Through this medium, children can understand rights from wrong and what their society holds in high esteem apart from what they consider taboos. Also, through artistic and imaginative devices, the folktale is used as a vital tool of drawing children's attention and developing and training them to be well-cultured individuals that are morally sound and virtuous.

Oral literature includes spoken, recited, or sung utterances composed and performed in an artistic character of vivid imagination, accurate observation, and creative expression (Falola \& Akinyemi, 2016; Nnyagu, 2017; Adeyinka \& Adegbodu, 2018). Like written literature imitates and mirrors society, oral literature preserves societal values, traditions, and beliefs. Furthermore, it is deeply rooted in culture, deploying highly artistic and emotive language to draw the listeners' attention. Values are collections of guiding principles about behaviors and attitudes that are desirable in life. Hornby (2005) describes values as beliefs about right and wrong of essential things in life. Values are observable in people's behavior, and society's responsibility is to impart those values that are dear to them to their children so that those children can inculcate them and act them out in their behaviors. Every society has some values and morals that it campaigns for and tries to share through generation. Through its creative spoken words of myth, proverbs, folktales, poems, songs, narratives, and riddles, oral literature passed communally from one generation to another preaches those values and virtues that are a particular sacrosanct community.

The rich reservoir of Nigeria's traditional heritage has afforded writers like D. Fagunwa and Amos Tutuola, who show Nigeria's music, worship, proverbs, and folklores in their works. In addition, several critical African literature writers like Chinua Achebe, Wole Soyinka, Gabriel Okara, Kofi Awoonor, and others have vividly incorporated the indigenous oral tradition of the Nigerian society. Okoh (2008) insinuated that the oral traditions in Nigeria were a precursor for written literature in the country. He expressly affirmed that the Igbo novel, poetry, or drama is the extension of the rich Igbo folktale.

Literature is integrated with the English language and called English Studies in the English Studies curriculum for Junior Secondary School students. This integration made it possible for the English language aspect to be taught and literature topics, oral literature included. This is to 
empower students to use the English language communicatively and decongest the curriculum. Both Non-African and African indigenous folklores of the Nigerian society like the Fulani myth, Yoruba folklores and epics, South African, Ghanaian folklore, myths, and several oral traditions of other nations like the Chinese myth, American folktales, etc. are included in the Literature aspect that Junior secondary school students are taught. The topics are incorporated alongside other language topics in the textbooks used across the nation.

Oral literature in the English Studies curriculum consists of folktales, myths, legends, and epics. The folktales are traditional stories handed over through generations to transmit societal values and virtues. Akporobaro (2006) describes those stories as fictional but used to entertain through their creative narration and intended to illuminate humanity's nature and moral conflicts like love, jealousy, endurance, persistence, etc. The folktale incorporates both human and animal characters to narrate human and non-human experiences that are fantastic. Lindfors (2002) comments that these fantastic stories are used to explain the foible of man's actions and behaviors. Often, folktales are didactic short stories. For instance, there are many about tortoise cleverness and slyness in cheating or stealing and the repercussions of his actions which reveals the foibles in the present society and the consequences of such moral conflicts. Folktales are didactic, entertaining, and magical. Being didactic, they are meant to teach morals, that is, the right ways of life and the values to members of the societies. They amuse and interest people, and that is why youngsters love gathering around and enjoying those stories being narrated to them to elderly ones in their community. Also, folktales are usually magical, with characters doing the impossible. Animals act, behave and talk like humans. Most folktales in Nigerian society usually revolved around tortoise, dog, lion, and elephant, with the inclusion of humans in some cases.

The myth looks similar to the folktale since both are short stories of fantastic tales. However, the myth is different since it makes use of mystical or supernatural characters. Myths are usually ancient stories invented to explain the beliefs, philosophies, natural and supernatural events (Nnyagu, 2017). These are stories used to explain the world in which we live, the existence of God, death, creation, life, and other beliefs. Every society in Africa has a varied myth of explaining the existence of God, the creation of the world, and other beliefs. Myths are usually magical, supernatural, and superstitious. Being magical, they make use of animals and humans that do things that look impossible and incredible. Most of the actions portrayed in myths are unexplainable by natural laws anchored by gods. Therefore, they are usually superstitious. Examples of these myths include in the African settings include The Fulani, Yoruba, Igbo, and Efik myths about creation.

On the other hand, Epics are long narrative stories or poems celebrating the heroic achievements of a legendary hero. The hero is usually one of supernatural strength or powerful man or woman who, through his/her intellectual or physical prowess, saves his/her society from perilous destruction. Examples of such in history include Moremi, Sango, and in Non-African tales, Beowulf. 
All these forms of oral literature are channels through which the diverse Nigerian cultures express their sacrosanct moral beliefs and values. In addition, various studies have reported that all these forms of oral literature mirror the societal realities and give insights into the philosophy inherent in those realities, thus helping to inculcate moral values to the younger generation (Pantic, 2006; Adeyinka \& Adegbode, 2018; Akinsola \& IIesanmi, 2018; Orotoye, 2019). These forms are valuable concepts appropriate for the English Studies curriculum that students are exposed to every weekday during their classroom interaction.

However, as the Nigerian communities opened themselves to civilization and globalization, the Western cultures found their way into the heart of the country. The new belief system began to war with the sacrosanct beliefs of the country such that the younger generation began to question mystical and sacred tales used to conceptualize and explain the beliefs. Currently, many teenagers and youths in Nigeria prefer the Western ways of life, such as their music, movies, and other entertainment modes, which often expose them to the mode of communication, dressing that are not in line with the value system of the Nigerian society. Little wonder the rate of moral decadence among secondary school students in Nigeria is on the increase, and it is evident in the persistent cases of fighting, violence, rape, examination malpractices, truancy, unruly behavior towards teachers, lying, aggression, even robbery, and cultism (Uche, 2000; Igbinoria, 2004; Egbochukwu \& Aihie, 2007; Agbo, 2010; Okebukola, 2012; Akinnawonu, 2018; Orotoye, 2019). In-school adolescents who are primarily junior secondary school students in the Ibadan metropolis are not exceptions to this prevailing crisis as their moral decadence status has become worrisome.

Since adolescent students in Nigeria are daily exposed to the content of English studies which is expected to have taught them the essential values that should translate to what they practice. It is expedient that the different English studies textbooks utilized in the junior secondary schools are evaluated to ascertain their content adequacy for teaching practical moral values to these adolescents. Therefore, this study was carried out to analyze the content adequacy of oral literature incorporated in New Oxford Secondary English Course for Junior Secondary Schools and New Concepts English Textbooks and investigate teachers' perceptions. Specifically, this study found answers to two questions. The first revealed how the selected English Studies Textbooks portray oral literature that could inculcate moral values in in-school adolescents. The second reported the teachers' perception about the content adequacy of the oral literature portrayed in the selected textbooks in inculcating moral values into in-school adolescents.

\section{Methods}

The study adopted the mixed methods (qualitative and quantitative) of data collection and analysis. Book one to three of New Oxford Secondary English Course for Junior Secondary Schools and New Concepts English Textbooks were purposively selected because they were used in the selected junior secondary schools for this study. The textbooks selected were content analyzed by drawing out their oral literature components and explaining how they portray oral literature that 
could inculcate moral values in in-school adolescents, as asked by the first research questions posed for this study.

Quantitative data were collected from 50 teachers of English studies randomly selected in the Ibadan metropolis. Five local government areas were enumerated in the Ibadan metropolis. The purposive sampling technique was used to select five public junior secondary schools in each of the five local government areas, making 25 schools. The criteria for the purposive selection was that the school has at least two qualified teachers of English and that the school uses the two English Studies textbooks (New Oxford Secondary English Course for Junior Secondary Schools and New Concepts English Textbooks) selected for the study. From each of the schools selected, two English studies teachers were selected, making a total of 50 teachers that took part in the study.

A self-constructed questionnaire named Questionnaire on Teachers' Perception of Oral Literature in English Studies Textbooks (QTPOLEST) was used for data collection. The questionnaire contains 25 items structured on the modified 4-point Likert scale of Strongly Agree (4), Agree (3), Disagree (2), Strongly Disagree (1). The questionnaire was face and content validated by two experts and after that trial-tested on 5 English Studies teachers in schools outside this study area. The Cronbach Alpha reliability method was used, and the reliability coefficient of .84 was obtained. After seeking the consent of the authorities of the schools selected, the researchers moved round to administer the questionnaire to the selected teachers in their leisure time. The questionnaire was retrieved on the spot. The administration of instruments and collation of data for the study lasted five weeks. Data collected were analyzed using descriptive statistics of frequency counts, percentage, mean and standard deviation.

\section{Results and Discussion}

\subsection{The Oral Literature Content of the Selected Textbooks}

The selected textbooks: New Concept for Junior Secondary School Schools (1-3) by Adeoye et al. (2018) and New Oxford Secondary English Course for Junior Secondary Schools (1-3) by Banjo et al. (2018) vividly discuss three elements of oral literature, which are: folktales, myths, and epics. Under the folktale, topical moral tales teaching wisdom, compassion, bravely, loyalty, honesty, and contentment are incorporated. For instance, the 'Nigerian-Tiv story about the cock and hare teaches one to live wisely and critically investigate actions before copying them.

Another folktale, a Ghanaian one titled, 'Why Anansi Has Eight Thin Legs,' is a story about a spider named Anansi, a greedy fellow who loved eating his friend's ready-made food despite having a wife who cooks delicious meals for him. His covetousness eventually caused him an accident that left him with eight skinny legs. From the story, the repercussion of greediness and the importance of being contented are vividly shown. 'The Lion's Whisker' is another folktale that teaches patience, courage, cleverness, bravery, and perseverance in attaining anything one sets his/her mind towards. With those qualities, individuals can achieve the unattainable. Some non- 
African folktales are also added in the textbooks; an example is an American tale titled 'Cow Head,' which also lends credence to the importance of compassion and bravery to having achievement in life.

The myth in the textbooks includes both non-African and African mythology about the creation of the world and the supernatural intervention of gods towards the affairs of men. For instance, the Greek myth titled 'An Unlucky Escape narrates the supernatural intervention of two sisters who were conspired against and fated to die but saved by the god, 'Hermes.' Another myth is titled 'The Sea and the Sun,' and it gives the reason why the sea and the sun are in their positions, one in the sky and the other on earth. Also, the Fulani myth about the creation of the world attempts to give some explanations about how the world came to be. The epics narrated in the textbooks narrates tales about valiant men and women of old like King Jaja of Opobo, Sango of Oyo, and MoremiAjaasoro of Ile-Ife. Those tales showcase integrity, valor, and diligence, which can be taught to students and guide them towards living life wisely. This aligns with previous studies such as Pantic, 2006; Adeyinka \& Adegbodu, 2018; Akinsola \& Ilesanmi, 2018; Orotoye, 2019, that reported the roles of oral literary forms in imparting moral values into young adolescents.

\subsection{Teachers' Perception About The Content Adequacy Of The Oral Literature Portrayed In The Selected Textbooks In Inculcating Moral Values Into In-School Adolescents}

Table 1 indicates the perception of English Studies teachers about the content adequacy of the oral literature portrayed in the selected textbooks in inculcating moral values into in-school adolescents, as expressed in frequency counts, percentage, the mean and standard deviation of the selected teachers' responses to each item. The weighted average of 3.16, which is far above the threshold (2.50), shows that the selected teachers positively perceived the content adequacy of the oral literature portrayed in the selected textbooks in inculcating moral values into in-school adolescents. The positive perception of the teacher, as shown through the items used, is based on the following themes:

a) The textbook's oral literature content teaches good human behavior

b) The textbook's oral literature content shows the evil in vicious acts

c) The content is relatable to students in their immediate environment

d) The content is capable of making students functional members of their society

e) The content teaches truthfulness and integrity

f) The content can instill discipline and love of hard work in students

g) The content portrayed heroic characters that students can model their lives on

h) The content teaches adequate wisdom for students' daily living. 
Table 1. Teachers' perception about the content adequacy of the oral literature portrayed in the selected textbooks in inculcating moral values into in-school adolescents

\begin{tabular}{|c|c|c|c|c|c|c|c|}
\hline $\mathbf{S} / \mathbf{N}$ & ITEMS & SA & A & D & SD & $\overline{\mathbf{x}}$ & St. D \\
\hline 1. & $\begin{array}{l}\text { The English Studies textbook I use in } \\
\text { teaching contains oral literary forms that } \\
\text { preach good human behaviors. }\end{array}$ & $\begin{array}{l}26 \\
(52 \%)\end{array}$ & $\begin{array}{l}24 \\
(48 \%)\end{array}$ & - & - & 3.52 & .504 \\
\hline 2. & $\begin{array}{l}\text { The textbook shows the evils in vicious } \\
\text { acts. }\end{array}$ & $\begin{array}{l}16 \\
(32 \%)\end{array}$ & $\begin{array}{l}34 \\
(68 \%)\end{array}$ & - & - & 3.32 & .471 \\
\hline 3. & $\begin{array}{l}\text { The textbook's oral literature content is at } \\
\text { variance with the values upheld in the } \\
\text { communities. }\end{array}$ & $\begin{array}{l}4 \\
(8 \%)\end{array}$ & - & $\begin{array}{l}40 \\
(80 \%)\end{array}$ & $\begin{array}{l}6 \\
(12 \%)\end{array}$ & 2.04 & .668 \\
\hline 4. & $\begin{array}{l}\text { The myth about the existence of God as } \\
\text { presented in the textbook is capable of } \\
\text { instilling religious values in students. }\end{array}$ & $\begin{array}{l}20 \\
(40 \%)\end{array}$ & $\begin{array}{l}8 \\
(16 \%)\end{array}$ & $\begin{array}{l}22 \\
(44 \%)\end{array}$ & - & 2.96 & .924 \\
\hline 5. & $\begin{array}{l}\text { The textbook contains oral literature that is } \\
\text { relatable to students in their immediate } \\
\text { environment. }\end{array}$ & $\begin{array}{l}9 \\
(18 \%)\end{array}$ & $\begin{array}{l}40 \\
(80 \%)\end{array}$ & $\begin{array}{l}1 \\
(2 \%)\end{array}$ & - & 3.16 & .421 \\
\hline 6. & $\begin{array}{l}\text { The moral lessons in the folktales } \\
\text { contained in the textbook can make } \\
\text { students functional members of their } \\
\text { society. }\end{array}$ & $\begin{array}{l}40 \\
(80 \%)\end{array}$ & $\begin{array}{l}3 \\
(6 \%)\end{array}$ & $\begin{array}{l}1 \\
(2 \%)\end{array}$ & $\begin{array}{l}6 \\
(12 \%)\end{array}$ & 3.54 & 1.01 \\
\hline 7. & $\begin{array}{l}\text { The folktales teach truthfulness and } \\
\text { integrity. }\end{array}$ & $\begin{array}{l}9 \\
(18 \%)\end{array}$ & $\begin{array}{l}40 \\
(80 \%)\end{array}$ & $\begin{array}{l}1 \\
(2 \%)\end{array}$ & - & 3.16 & .421 \\
\hline 8. & $\begin{array}{l}\text { The oral literature portrayed in the } \\
\text { textbook can instill discipline and love of } \\
\text { hard work in students. }\end{array}$ & $\begin{array}{l}25 \\
(50 \%)\end{array}$ & $\begin{array}{l}25 \\
(50 \%)\end{array}$ & - & - & 3.50 & .505 \\
\hline 9. & $\begin{array}{l}\text { The myths in the text exemplify heroic } \\
\text { characters that students can model their } \\
\text { lives on. }\end{array}$ & $\begin{array}{l}24 \\
(48 \%)\end{array}$ & $\begin{array}{l}21 \\
(42 \%)\end{array}$ & $\begin{array}{l}5 \\
(10 \%)\end{array}$ & - & 3.38 & .666 \\
\hline 10. & $\begin{array}{l}\text { Students cannot learn good virtues from } \\
\text { many African legends represented in the } \\
\text { textbook. }\end{array}$ & $\begin{array}{l}22 \\
(44 \%)\end{array}$ & $\begin{array}{l}24 \\
(48 \%)\end{array}$ & $\begin{array}{l}1 \\
(2 \%)\end{array}$ & $\begin{array}{l}3 \\
(6 \%)\end{array}$ & 3.30 & .788 \\
\hline 11. & $\begin{array}{l}\text { The oral literature in the textbook provides } \\
\text { adequate wisdom for their daily living. }\end{array}$ & $\begin{array}{l}18 \\
(36 \%)\end{array}$ & $\begin{array}{l}22 \\
(44 \%)\end{array}$ & $\begin{array}{l}10 \\
(20 \%)\end{array}$ & - & 3.16 & .738 \\
\hline 12. & $\begin{array}{l}\text { The oral literature content of the English } \\
\text { textbook I use in teaching is enough for } \\
\text { inculcating moral values into my students. }\end{array}$ & $\begin{array}{l}6 \\
(12 \%)\end{array}$ & $\begin{array}{l}34 \\
(68 \%)\end{array}$ & $\begin{array}{l}10 \\
(20 \%)\end{array}$ & - & 2.92 & .565 \\
\hline
\end{tabular}

Weighted Average $=3.16$; Threshold $=2.50$

From the preceding, the analysis conducted revealed that the selected textbooks have three elements of oral literature, which are: folktales, myths, and epics. The content analysis of the folktales, myths, and epics portrayed in the textbooks revealed that they teach wisdom, compassion, bravely, loyalty, honesty, and contentment. Teachers' perception of the adequacy of these oral literature contents corroborated this. In other words, teachers' perception of the adequacy of the oral literature content of the textbooks in instilling moral values into junior secondary school students was positive. If the English studies instruction/lesson is qualitative, junior secondary school students should be moral in schools where these textbooks are used. The findings corroborated Nwakaego (2016) view that society usually uses folktales, folksongs, riddles, and proverbs as pedagogic tools for supplementing any deficiency they note in children's values and behaviors. The 
inculcation of such oral literature into English studies textbooks is that students practice moral values and behave in a way acceptable to the community where they live.

The findings also gave support to the opinion of Akporobaro (2006) oral literature are intended to illuminate humanity's nature and moral conflicts like love, jealousy, endurance, persistence, etc., as well as the comment of Lindfors (2002) that such stories are used to explain the foible of man's actions and behaviors. There is, therefore, no doubt that the incorporation of such oral literature content into the junior secondary school English textbook is to see to the moral and holistic development of children and adolescents, whom these days may no longer stay much at home with a parent who could instill moral values in them through the instrumentality of oral literary forms.

\section{Conclusions}

Based on the study's findings, it is clear that textbook content is not that responsible for the moral decadence observed among the in-school adolescents as other factors would. However, the study did not ascertain the level of teacher implementation of the oral literature content portrayed in the textbooks, for a well-designed program and a well-written textbook would not implement and use itself. Therefore, the moral decadence observed among the in-school adolescents may be due to the poor or no implementation of the oral literature content of the English Studies textbooks, despite the high portrayal of moral values and the positive perception of teachers about them. It could also be due to the non-possession of the texts by the students. Hence, the teacher would be incapacitated in the use of the textbook. Other environmental variables and civilization-related factors may also be responsible for such a level of moral decadence among junior secondary school students. Based on the findings of this study and the conclusion drawn, the following recommendations were made: a) english teachers at the junior secondary school level should actively implement the oral literature content of the English studies textbook with the use of appropriate teaching methods, strategies, and instructional materials; b) parents and guardians should ensure that their children and wards have the prescribed English studies textbooks; c) parents should resuscitate the moonlight stories and other oral narratives through which children could imbibe cultural values and moral behaviors; $d$ ) educators should conduct more studies on the factors responsible for moral decadence among inschool adolescents so that that appropriate solution could be proffer.

\section{References}

Adeoye, Adam, Eto, Eyisi J., Adekunle \& Adepoju (2018). New Concept English for Junior Secondary Schools Bk 1-3. Lagos: Learn Africa Publishers.

Adeyinka, A.A. \&Adegbodu, Z.O. (2018). The Metaphysical and Emotional Impact of Oriki in Yoruba Belief: A Case Study of Alaafin of Oyo. Akungba Journal of Linguistics and Literatures 9 (Special Edition), 73-82.

Agbo, D.C. (2010). The Rise and Fall of Education Standard in Nigeria: Implication and the Way Forward. Enugu: El Denmrk Publishers. 
Akinnawonu, B.M. (2018), TheEpistemologyical and Ethical Significance of the Yoruba Concepts of Omoluabi. Akungba Journal of Linguistics and Literatures 9 (Special Edition), 26-31.

Akporobaro F.B.O.(2006). Introduction to African Oral Literature. Lagos: Princeton Publishing Company.

Amin Mt, M. \& Ahmed, T. (2021). Challenges Faced by Teachers about Inculcating Islamic Values: Pilot Inquiry. International Journal of Social Learning 1 (2), 135-146. Retrieved June 3, 2021, from DOI: https://doi.org/10.47134/ijsl.v1i2.11

Banjo, A. Adeniran, A. Akano, A.\&Onaga, U. (2018).New Oxford Secondary English Course for Junior Secondary Schools, 1-3.Ibadan: University Press PLC.

Egbochukwu, E.O. \&Aihie, N.O. (2007). Influence of Peer Group, Counseling and Family Type on Self-Concept of Secondary School Adolescents in Benin City. African Journal of Studies in Education, 3 (1), 48-58.

Fafunwa, A.B. (1991).History of Education in Nigeria. Onitsha: NPS Educational Publishers Limited.

Falola, T. \&Akinyemi, A. (2016). Encyclopedia of the Yoruba. USA: Indiana University Press.

Hornby, A.S. (2005). Oxford Advanced learner's University Press. Dictionary of Current English. Oxford University Press

Igbinoria, L. (2004). Challenges in Higher Education in Nigeria. Unpublished paper, Ibadan, July 21.

Lindfors, B. (2002). Folklore in Nigerian Literature. Ibadan: Caltrop.

Nnyagu, U. (2017). The Nature of Oral Literature: Concepts and Genres. Scholars Journal of Arts, Humanities and Social Sciences.5 (9), 1149-115

Nwakaego, N. (2016). Oral Literature as a Spring-Board for Value Inculcation to Children. British Journal of Education 4 (11), 1-10.

Okebukola, P. (2012). Moral Instruction in Nigerian Schools for National Transformation. Address delivered at the prize-giving day and Valedictory Service of Preston International School, Akure, Nigeria.

Okoh, N. (2008).Preface to Oral Literature. Port Harcourt: Lamison Publishers.

Orotoye, T.A. (2019). The Symbolic Role of Oral Poetry in the Sustainability of African Sociocultural Space: Example of the Oriki of Oluwo of Iwo. First Conference of the International Association of Language Educators, 12-15 September 2019, Ile-Ife Nigeria. Pantic, N. (2006). Moral Education Through Literature. 38(2), 401-414.

Uche, A. N. (2000). New Perspective in Moral Education. Ibadan: Evans Brother Nig. 